\title{
JUSTICE DICKSON'S CIVIL TORT LAW JURISPRUDENCE
}

\author{
ROGER PARDIECK* \\ KAREN DAVIS ** \\ MAGGIE SMITH $^{* * *}$
}

\section{INTRODUCTION}

Justice Dickson's thirty-year tenure on the Indiana Supreme Court was marked by an enduring effort to provide litigants with a forum to have their cases heard. Justice Dickson strove to ensure that the Indiana Constitution was given its own significance apart from the U.S. Constitution, while taking care to delineate the role of the court from the role of the legislature.

His legacy will be reflected for years to come in Indiana civil tort law jurisprudence, especially given his landmark decisions in such cases as Jarboe v. Landmark Community Newspapers of Indiana ${ }^{1}$ and Myers v. Crouse-Hinds Division of Cooper Industries, ${ }^{2}$ as well as his influential dissents in cases such as Allied Signal v. Ott ${ }^{3}$ and McIntosh v. Melroe. ${ }^{4}$

Above all, Justice Dickson's civil tort law jurisprudence was characterized by a commitment to pragmatism, fairness, reasonableness, and an abiding trust in the jury system. Emblematic of this confidence in jurors, Justice Dickson wrote the opinion in Clark v. Clark to repudiate an earlier decision from the 1970s that impugned the jury's ability to provide justice:

$[\mathrm{W}] \mathrm{e}$ take this opportunity to disapprove certain unfortunate language in

* Roger Pardieck founded The Pardieck Law Firm in his home town of Seymour, Indiana, on the principle that the civil justice system is the most powerful instrument for change in our society. Mr. Pardieck received his undergraduate degree and his law degree from Indiana University and has practiced in Seymour, Indiana throughout his career. He served as special prosecutor in Jackson County for two years before starting his civil practice in 1965.

** Karen Davis is an attorney at The Pardieck Law Firm in Seymour, Indiana. She graduated with a bachelor's degree in journalism in 1987 and graduated cum laude from Indiana University School of Law-Bloomington in 1994.

*** Maggie L. Smith is a 1996 magna cum laude graduate of the University of Arizona School of Law and was a visiting third-year student at Indiana University School of LawBloomington. Following graduation, she clerked for the Indiana Supreme Court, Hon. Brent E. Dickson, and served as an adjunct professor of law at Indiana University. Ms. Smith is counsel with the Midwest firm Frost Brown Todd.

The authors would like to thank Haley Clough, former law clerk with The Pardieck Law Firm, for her assistance with the early stages of this article. Ms. Clough is a 2016 graduate of Maurer Law School at Indiana University-Bloomington.

1. 644 N.E.2d 118 (Ind. 1994).

2. 53 N.E.3d 1160 (Ind. 2016).

3. 785 N.E.2d 1068 (Ind. 2003).

4. 729 N.E.2d 972 (Ind. 2000).

5. 971 N.E.2d 58 (Ind. 2012). 
Sidle $\left[v\right.$. Majors $\left.^{6}\right]$ which we find to undermine and misstate wellestablished important values and principles of Indiana and American jurisprudence. The Sidle opinion speculated with approval that "a very likely legislative policy" may have been "protection against the 'benevolent thumb syndrome", and "the 'Robin Hood' proclivity of juries."

Such language improperly mischaracterizes the conscientious, insightful, and reliable efforts of those who serve as jurors. It has no proper place in our jurisprudence. ${ }^{7}$

\section{SUMmARY JUdGMENT STANDARD: “OPEN COURTS” IN INDIANA}

\section{$A$. Jarboe v. Landmark Community Newspapers of Indiana}

Justice Dickson's influential decision in Jarboe v. Landmark Community Newspapers of Indiana, involving the summary judgment standard, reflects his commitment to the "open courts" concept embodied in the Indiana Constitution. ${ }^{8}$ Jarboe was a wrongful discharge case in which the plaintiff asserted that the doctrine of promissory estoppel prevented his employer from terminating him. ${ }^{9}$ The defendant employer argued the plaintiff did not present specific material facts to support promissory estoppel. ${ }^{10}$ However, the defendant did not submit its motion with any designated evidence that established the absence of a question of fact on a material issue. ${ }^{11}$

Justice Dickson explained in his majority opinion that Indiana's summary judgment standard must be distinguished from the federal summary judgment standard set out by the U.S. Supreme Court. ${ }^{12}$ Under Celotex Corp. v. Catrett, ${ }^{13}$ the party moving for summary judgment is not required to introduce any evidence negating its opponent's claim. ${ }^{14}$ However, the Indiana summary judgment standard requires that the movant demonstrate the absence of any genuine issue of fact as to a determinative issue. ${ }^{15}$ Only then is the non-movant required to come forward with contrary evidence. ${ }^{16}$ The movant cannot secure summary

6. 341 N.E.2d 763 (Ind.1976).

7. 971 N.E. $2 d$ at 61 n.1.

8. See 644 N.E.2d 118, 123 (Ind. 1994); see also McIntosh v. Melroe Co., 729 N.E.2d 972, 985-86 (Ind. 2000) (Dickson, J., dissenting) (arguing the Indiana Constitution provides for open courts and guarantees those who had injury done to them an affirmative remedy in the law).

9. 644 N.E. $2 \mathrm{~d}$ at 120.

10. Id. at 121 .

11. Id. at 123 .

12. $I d$.

13. 477 U.S. 317 (1986).

14. Id. at 323 .

15. Jarboe, 644 N.E.2d at 123.

16. Id. 
judgment by merely showing its opponent lacks evidence on an element of the non-movant's cause of action. ${ }^{17}$

The Jarboe standard reflects Indiana's policy-and Justice Dickson's commitment to promoting the policy - that summary judgment should not be used as a cursory trial. ${ }^{18}$ Justice Dickson's desire to keep the courthouse doors open is reflected in this standard.

\section{B. Jarboe's Progeny}

The Indiana Court of Appeals applied Jarboe in Lenhardt Tool \& Die Co. v. Lumpe, holding that the defendant did not carry its summary judgment burden merely by alleging the plaintiff lacked evidence that the defendant made the mold in question. ${ }^{19}$ In Lenhardt, the plaintiff alleged that she was injured by a mold made and sold by the defendant. ${ }^{20}$ The defendant moved for summary judgment on the issue of whether it machined the mold in question. ${ }^{21}$ In support of its motion, the defendant merely alleged that the plaintiff had not offered sufficient evidence, but it did not itself proffer probative evidence that it did not machine the mold. ${ }^{22}$ The court held Lenhardt would have had to designate some evidence that it did not manufacture the mold in order to require the plaintiff to come forward with contrary evidence. ${ }^{23}$ The defendant's showing that the plaintiff, Lumpe, did not designate sufficient evidence to prove the mold was manufactured by the defendant was not enough for Lenhardt to succeed on its motion for summary judgment. ${ }^{24}$

Jarboe's result, considered in light of the holding in Lenhardt, is that plaintiffs may survive summary judgment even though they will not later survive a motion for judgment on the evidence under Indiana's T.R. 50 standard. $^{25}$ However, as Chief Judge Sharpnack acknowledged in Lenhardt, "[T]he dictate of Jarboe is consistent with the recognition that summary judgment terminates the right to trial and that summary judgment will be denied even though it appears that the plaintiff may not succeed at trial.".26

Following the appellate court's affirmation of the denial of summary judgment, Lenhardt filed a petition to transfer, which was denied ${ }^{27}$ However, the distinction between the federal and Indiana summary judgment standards would

17. $I d$.

18. See Hughley v. State, 15 N.E.3d 1000, 1003-04 (Ind. 2014).

19. 703 N.E.2d 1079, 1083 (Ind. Ct. App. 1998).

20. Id. at 1081 .

21. Id. at 1080 .

22. Id. at 1081 .

23. Id. at 1083 .

24. Id

25. See id. at 1083-84; IND. R. TR. P. 50.

26. 703 N.E.2d at 1083-84 (citing Greathouse v. Armstrong, 616 N.E.2d 364, 365-366 (Ind. 1993)).

27. Lenhardt Tool \& Die Co. v. Lumpe, 722 N.E.2d 824, 824 (Ind. 2000). 
be questioned over the following years. ${ }^{28}$ Justice Boehm wrote a dissent to Lenhardt's petition to transfer, in which Chief Justice Shepard concurred. ${ }^{29}$ Boehm wrote that under both Indiana and federal standards, summary judgment should be granted if the movant establishes by "undisputed facts either that (1) the non-movant will be unsuccessful as a matter of law or (2) the non-movant will be unable at trial to establish an essential fact on which the non-movant carries the burden of proof." 30

The Indiana Court of Appeals continued to question the wisdom of Jarboe in the following years, issuing at least two opinions that called on the Indiana Supreme Court to clarify the holding: Cole v. Gohmann, ${ }^{31}$ and Deuitch v. Fleming. ${ }^{32}$ The Deuitch court wrote, "Thus, applying the standard as articulated in Jarboe permits a plaintiff who has no evidence supporting his claim to proceed to trial, thereby wasting the parties' time and money as well as judicial resources. One would hope that this anomaly would be addressed by the supreme court." 33

The Indiana Supreme Court addressed the issue in 2014 by reaffirming the wisdom of the Jarboe holding in Hughley v. State. ${ }^{34}$ Chief Justice Rush wrote for the majority that "while federal practice permits the moving party to merely show that the party carrying the burden of proof lacks evidence on a necessary element, we impose a more onerous burden: to affirmatively 'negate an opponent's claim." "'35 She described summary judgment as a desirable tool that allows courts to dispose of cases only involving legal issues, and wrote, "In essence, Indiana consciously errs on the side of letting marginal cases proceed to trial on the merits, rather than risk short-circuiting meritorious claims. ${ }^{~} 36$

Thus, Justice Dickson's landmark holding in Jarboe helped pave the way for Indiana to strengthen its open courts policy, and has proven to be the proper analysis for summary judgment issues. ${ }^{37}$

\section{Right TO REMEDY AND EQUAL TREATMENT IN INDIANA Product Liability CASES}

Justice Dickson's commitment to keeping the courthouse doors open did not end with Jarboe; he continued to fight for litigants' constitutional rights in products liability and asbestos cases. ${ }^{38}$

28. See, e.g., id. at 826-27 (Boehm, J., dissenting).

29. Id. at 825,828 .

30. Id. at $826-27$.

31. 727 N.E.2d 1111 (Ind. Ct. App. 2000).

32. 746 N.E.2d 993 (Ind. Ct. App. 2001).

33. Id. at 1000 .

34. 15 N.E.3d 1000 (Ind. 2014).

35. Id. at 1003 (emphasis in original) (citing Jarboe v. Landmark Cmty. Newspapers, 644 N.E.2d 118, 123 (Ind. 1994)).

36. Id. at 1003-04.

37. Id.

38. See infra Parts II.A-B. 


\section{A. Indiana Product Liability Statute of Repose}

Justice Dickson wrote a strong dissent in McIntosh v. Melroe ${ }^{39}$ arguing that the Indiana product liability statute of repose violated article 1, sections 12 and 23 of the Indiana Constitution. ${ }^{40}$ In McIntosh, the plaintiff challenged the Indiana Product Liability Act (IPLA) statute of repose as violating the Indiana Constitution. ${ }^{41}$ The general statute of limitations for products liability cases in Indiana states that, except as provided in an asbestos exception to the statute, "a product liability claim must be commenced: (1) within two (2) years after the cause of action accrues; or (2) within ten (10) years after the delivery of the product to the initial user or consumer." ${ }^{42}$ In McIntosh, the plaintiff had been injured by the defendant's Bobcat skid steer loader. ${ }^{43}$ Justice Boehm, writing for the majority, held that because the plaintiff's injury occurred more than ten years after the product's delivery to the initial user or consumer, the plaintiff's claim was barred by the statute of repose in Indiana Code section 34-20-3-1(b)(2). ${ }^{44}$

Justice Dickson's dissent challenged the majority's upholding of the constitutionality of the IPLA statute of repose under article 1, section 12 of the Indiana Constitution. ${ }^{45}$ Section 12 states, "All courts shall be open; and every person, for injury done to him in his person, property, or reputation, shall have remedy by due course of law." 46 The majority held the Indiana Legislature has the ability to modify or abrogate common law rights and remedies and has the authority to determine which injuries are wrongs for which there is a legal remedy. ${ }^{47}$ The majority distinguished Martin $v$. Richey in which it held the medical malpractice statute of limitations was unconstitutional as applied to the plaintiff. ${ }^{48}$ The majority reasoned that Martin had a claim that would have been taken away from her because she could not have discovered her injury within the statute of limitations period, in contrast to McIntosh, whose claim never accrued because he was not injured within ten years. ${ }^{49}$

Justice Dickson's dissent expressed his belief that the right to remedy for injury was one of the "core values" of the Indiana Constitution. ${ }^{50} \mathrm{He}$ wrote,

39. 729 N.E.2d 972 (Ind. 2000).

40. Id. at 990, 994 (Dickson, J., dissenting).

41. Id. at 974 (majority opinion).

42. IND. CODE § 34-20-3-1 (2014) (“However, if the cause of action accrues at least eight (8) years but less than ten $(10)$ years after th[e] initial delivery, the action may be commenced at any time within two (2) years after that cause of action accrues.").

43. 729 N.E. $2 d$ at 973.

44. Id. at 980 .

45. Id. at 990 (Dickson, J., dissenting).

46. IND. CONST. art. $1, \S 12$.

47. McIntosh, 729 N.E.2d at 978.

48. Id. (citing 711 N.E.2d 1273, 1279 (Ind. 1999)).

49. Id. (citing 711 N.E.2d at 1281).

50. See id. at 989 (Dickson, J., dissenting). 
"While legislative qualifications of this right may be enacted under the police power, the total abrogation of an injured person's right to remedy is an unacceptable material burden." ${ }^{51} \mathrm{He}$ recognized that the statute of repose "completely bars the courthouse doors to all persons injured by products over ten years old, even for claims alleging negligence, and even where the products were designed, built, sold, and purchased with the expectation of decades of continued use." 52

His dissent also challenged the majority's upholding of the constitutionality of the IPLA statute of repose under article 1, section $23 .{ }^{53}$ Section 23 provides, "The General Assembly shall not grant to any citizen, or class of citizens, privileges or immunities, which, upon the same terms, shall not equally belong to all citizens." ${ }^{54}$ The majority held the statute was constitutional because it classified the products, not the claimants, and any distinction made between the claimants was rationally related to the legislature's goals. ${ }^{55}$

Justice Dickson's dissent explained that the statute impermissibly created two classes of persons for unequal treatment: those injured within ten years of delivery of the product, and those injured more than ten years after the delivery. ${ }^{56}$ $\mathrm{He}$ reasoned that courts ought to analyze how a statute classifies people, not products, and then decide if the treatment is unequal. ${ }^{57} \mathrm{He}$ explained, "[T]he Indiana Constitution demands more than simply a rational relationship between the legislative goal and the classification.... All people should have equal access to seek remedy for injuries they suffer, and those responsible should be held accountable. The interests of justice demand nothing less."

\section{B. Asbestos Cases}

Prior to McIntosh, Justice Dickson wrote a strong dissent in Covalt v. Carey Canada, Inc. ${ }^{59}$ calling for an analysis of the asbestos statute of limitations under the Indiana Constitution. ${ }^{60} \mathrm{He}$ emphasized the importance of Indiana constitutional analysis and respect for the doctrine of separation of powers, particularly between the judicial and legislative branches of government. ${ }^{61}$ In Covalt, the majority held the IPLA statute of repose did not apply "to cases involving protracted exposure to an inherently dangerous foreign substance which

51. Id.

52. Id.

53. Id. at 990-94.

54. IND. CONST. art. 1, § 23.

55. McIntosh, 729 N.E.2d at 982-84.

56. Id. at 991 (Dickson, J., dissenting).

57. Id. at $991-92$.

58. Id. at $992,994$.

59. 543 N.E.2d 382 (Ind. 1989).

60. Id. at 390 (Dickson, J., dissenting).

61. Id. 
is visited into the body." ${ }^{92}$ The majority did not conduct a constitutional analysis and also stated it could not determine if the legislature intended the ten-year statute of repose to bar claims where the injury is the result of protracted exposure to a hazardous foreign substance. ${ }^{63}$ The majority explained that to require a claimant to bring his action in a limited period in which, even with due diligence, he could not be aware that a cause of action exists would be inconsistent with our system of jurisprudence. ${ }^{64}$

Justice Dickson dissented, writing that the court "may not substitute its judgment for that of the legislature. ${ }^{.65}$ Absent constitutional infirmity, the statute of repose must be applied to products liability cases filed more than ten years after the date the product was delivered to the initial user or consumer. ${ }^{66} \mathrm{He}$ suggested, however, that the statute ought to be reviewed under article 1, sections 12 and 23 of the Indiana Constitution. ${ }^{67}$ This dissent was before his dissent in McIntosh, in which he strongly argued that the majority's interpretation of the IPLA statute of repose violated sections 12 and $23 .^{68}$ Justice Dickson's reasoning in Covalt paved the way for his dissent in McIntosh, as well as his more recent dissent in Allied Signal v. Ott. ${ }^{69}$

In $\mathrm{Ott}$, the court construed the statutory exception to the IPLA statute of repose for asbestos claims. ${ }^{70}$ This statutory exception provides that asbestos claims against persons who mined and sold commercial asbestos can be brought within two years after the cause of action accrues. ${ }^{71}$

62. Id. at 385 (majority opinion).

63. Id.

64. Id. at 387.

65. Id. at 389 (Dickson, J., dissenting).

66. Id. at 390 .

67. Id.

68. See supra Part II.A.

69. See 785 N.E.2d 1068, 1078-84 (Ind. 2003) (Dickson, J., dissenting)

70. See generally id.

71. IND. CODE $\S 34-20-3-2$ (1998) provides:

(a) A product liability action that is based on:

(1) property damage resulting from asbestos; or

(2) personal injury, disability, disease, or death resulting from exposure to asbestos;

must be commenced within two (2) years after the cause of action accrues. The subsequent development of an additional asbestos related disease or injury is a new injury and is a separate cause of action.

(b) A product liability action for personal injury, disability, disease, or death resulting from exposure to asbestos accrues on the date when the injured person knows that the person has an asbestos related disease or injury.

(c) A product liability action for property damage accrues on the date when the injured person knows that the property damage has resulted from asbestos.

(d) This section applies only to product liability actions against:

(1) persons who mined and sold commercial asbestos; and 
The majority interpreted the statutory language "who mined and sold commercial asbestos" as modifying "persons" in such a way as to require that a defendant have both mined and sold asbestos in order for the plaintiff's claim to not be barred by the statute of repose in Indiana Code section 34-20-3-1(b)(2). ${ }^{72}$ Justice Dickson, however, interpreted the statute differently, focusing on an interpretation that did not render statutory language superfluous. ${ }^{73}$ Considering the whole statute, he found the legislature intended to include products containing asbestos when it used the term "commercial asbestos." "Th This interpretation would mean that the asbestos statute of limitations applied to the plaintiffs' claims, but the statute of repose would not. ${ }^{75} \mathrm{He}$ also found compelling evidence to suggest the legislature intended the statutory exception to apply to claims against persons who mined asbestos and claims against persons who sold asbestos, not just claims against persons who did both. ${ }^{76} \mathrm{He}$ emphasized that the majority's interpretation would make "mined and sold" obsolete, because of the unlikeliness that there are entities that mine but do not sell asbestos. ${ }^{77}$ Justice Dickson stressed that "legislative intent will prevail over the literal import of the words."78

Justice Dickson also disagreed with the majority's constitutional analysis in $O t t$. Since the majority held the statutory exception in Indiana Code section 3420-3-2 did not apply to the Ott plaintiffs, it considered whether the statute of repose in Indiana Code section 34-20-3-1 violated article 1, section 12 of the Indiana Constitution. ${ }^{79}$ The majority held a cause of action for an asbestos-related disease accrues when the disease manifests itself, which is when a reasonably experienced physician could have diagnosed the plaintiff with an asbestos-related illness or disease ${ }^{80}$ The majority further held the only situation in which the statute of repose would be unconstitutional is where it applied to a plaintiff who was injured within ten years of initial delivery and a reasonably experienced physician could have made the proper diagnosis, but the plaintiff had no reason

(2) funds that have, as a result of bankruptcy proceedings or to avoid bankruptcy proceedings, been created for the payment of asbestos related disease claims or asbestos related property damage claims.

(e) For the purposes of I.C. 1-1-1-8, if any part of this section is held invalid, the entire section is void.

(f) Except for the cause of action expressly recognized in this section, this section does not otherwise modify the limitation of action or repose period contained in section 1 of this chapter.

72. Ott, 785 N.E.2d at 1073.

73. Id. at 1080 (Dickson, J., dissenting).

74. Id. at 1078-79.

75. Id. at 1084 .

76. Id. at $1079-81$.

77. Id. at 1080 .

78. Id. (citing FGS Enters., Inc. v. Shimala, 625 N.E.2d 1226, 1228 (Ind. 1993)).

79. Id. at 1073-76 (majority opinion).

80. Id. at 1075 . 
to know of the diagnosable condition until after the ten-year period. ${ }^{81}$

Justice Dickson's dissent, however, argued that the majority's application of the statute violated the plaintiffs' right to remedy under article 1, section 12 of the Indiana Constitution. ${ }^{82} \mathrm{He}$ found Ott could not have discovered he had an asbestos-related disease within the ten-year statute of repose, and a claim that exists cannot be barred before it is known to exist. ${ }^{83}$ Additionally, regarding the interpretation of "accrues," the majority focused on when a physician could have diagnosed the injury instead of when the plaintiff became aware of it. ${ }^{84}$ This was impermissible, he argued, because the legislation itself focuses on when the injured person knew of the injury in determining when the claim accrues. ${ }^{85}$

Finally, Justice Dickson's dissent pointed out the majority's failure to adhere to the test the court set forth in Collins v. Day ${ }^{86}$ In Collins, the court held section 23 "prohibits a statute from providing disparate treatment to different classes of persons if: (1) the disparate treatment is not reasonably related to inherent characteristics that distinguish the unequally treated classes, or (2) the preferential treatment is not uniformly applicable and equally available to all similarly situated persons. ${ }^{87}$ Justice Dickson determined that the statute, as interpreted by the $O t t$ majority, grants unequal treatment to individuals who contract asbestos diseases from exposure to raw asbestos, compared to those whose diseases are caused by exposure to asbestos-containing products. ${ }^{88}$ These two classes of individuals are not distinguished by inherent characteristics, so they ought to be treated equally. ${ }^{89}$

Justice Dickson's asbestos jurisprudence not only displays his respect for the Indiana Constitution and the separation of powers doctrine, but also for the doctrine of stare decisis. Although he dissented in Allied Signal v. Ott, his majority opinion in Myers $v$. Crouse-Hinds Division of Cooper Industries declined to reconsider the majority's ruling in Ott due to the principles of stare decisis and legislative acquiescence. ${ }^{90}$ Instead of overruling Ott, Justice Dickson's majority opinion in Myers concluded that the plaintiffs had raised a constitutional argument under the privileges and immunities clause of the Indiana Constitution that was different than the privileges and immunities argument in $\mathrm{Ott} .{ }^{91} \mathrm{In} O t t$, the class division considered was asbestos victims versus other victims under the IPLA. In Myers, the class division considered was between asbestos victims with claims against defendants who both mined and sold raw asbestos and all other

81. Id.

82. Id. at 1081-82 (Dickson, J., dissenting).

83. Id.

84. Id. at 1082 .

85. Id.; IND. CODE $\S 34-20-3-2$ (b) (2003).

86. Id. at 1083-84 (citing 644 N.E.2d 72, 80 (Ind. 1994)).

87. Id. at 1083 (citing 644 N.E.2d at 80 ).

88. Id.

89. Id.

90. Myers v. Crouse-Hinds Div. of Cooper Idus., 53 N.E.3d 1160, 1162 (Ind. 2016).

91. Id. at 1164 . 
asbestos victims. ${ }^{92}$ The court held the IPLA's statute of limitations found in Indiana Code section 34-20-3-2 was unconstitutional. ${ }^{93}$

In Myers, the plaintiffs brought suit alleging damages stemming from asbestos-caused diseases. ${ }^{94}$ The Indiana Supreme Court consolidated three cases to decide whether the plaintiffs' claims were barred under $O t t .{ }^{95}$ In Ott the court held section 2 of the IPLA, which applies to asbestos-related actions, exempts from the statute of repose only those plaintiffs bringing claims against defendants who both mined and sold raw asbestos. ${ }^{96}$ This left all other asbestos plaintiffs within the ambit of the section 1 statute of repose. Justice Dickson renewed the argument he made in his $\mathrm{Ott}$ dissent in the majority opinion in Myers. ${ }^{97}$ In Myers, the court held Indiana Code section 34-20-3-2 unconstitutional because it resulted in the creation of two disparately treated classes: (1) asbestos victims injured by defendants who both mined and sold raw asbestos and (2) asbestos victims injured by defendants who provided asbestos-containing products. ${ }^{98}$ The court explained there was no inherent distinguishing characteristic between these two classes of plaintiffs, and because they are similarly situated, they ought to be treated uniformly..$^{99}$ Under the IPLA statute of repose, however, they are not treated uniformly because only one group is completely exempted. On this basis, the court held Indiana Code section 34-20-3-2 unconstitutional. ${ }^{100}$

Because the asbestos statute of limitations was held to be unconstitutional and did not govern these claims, the Myers majority held all asbestos plaintiffs now fall under the statute of repose provision in Indiana Code section 34-20-3-1. ${ }^{101}$ Justice Dickson referred back to Ott and Covalt to analyze the applicability of the statute of repose for the plaintiffs in Myers. ${ }^{102}$ Ott had partially overruled Covalt based on the enactment of section $2 .{ }^{103}$ Because section 2 was rendered void, Myers restored Covalt as controlling precedent. Therefore, the statute of repose did not apply to cases involving protracted exposures to an inherently dangerous foreign substance. ${ }^{104}$

Myers is an excellent example of Justice Dickson's respect for stare decisis, separation of powers, and the Indiana Constitution. His opinion declined to needlessly reconsider a ruling from which he had previously dissented; he recognized that this would unnecessarily interfere with the doctrine of stare

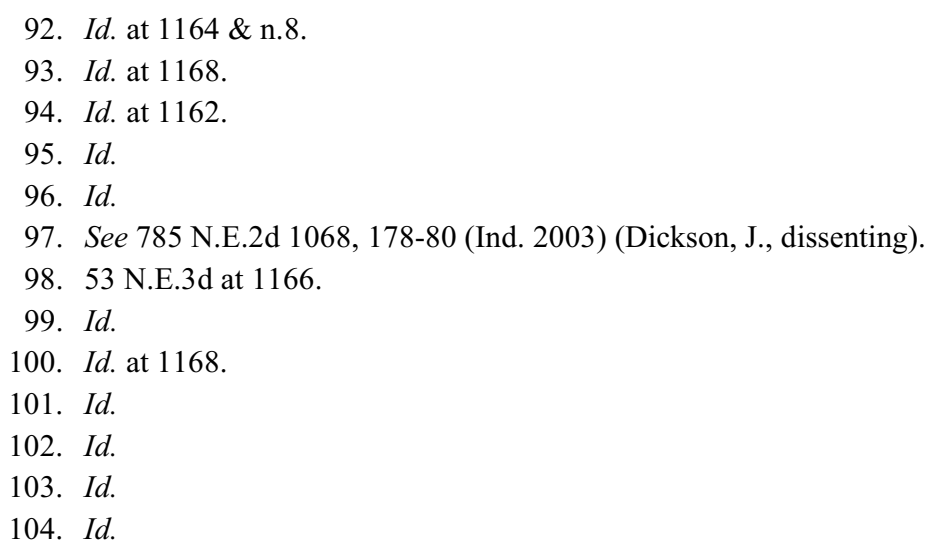


decisis. ${ }^{105}$ Instead, the case was decided on a yet unanswered Indiana constitutional question, thereby strengthening and clarifying Indiana constitutional jurisprudence. ${ }^{106}$ Finally, Myers attempted to increase courtroom access for asbestos plaintiffs in Indiana, an important goal given article 1, section 12 of the state constitution. ${ }^{107}$

\section{Wrongful Life, Wrongful Death, And Attorney Fees}

\section{A. Wrongful Life and Wrongful Death}

In Cowe v. Forum Group, Inc., ${ }^{108}$ a male patient in a nursing home's care raped one of the nursing home's incapacitated female patients, resulting in the birth of the plaintiff. ${ }^{109}$ The plaintiff sued the nursing home asserting, among other things, a cause of action for "wrongful life" based on his claim that he was born "into a world in which there was no natural parent capable of caring for and supporting him."110

Justice Dickson's majority opinion began by noting that a "wrongful life" claim traditionally involves damages brought by "a child born with birth defects alleging that due to negligent medical advice or testing they were precluded from an informed decision about whether to conceive a potentially handicapped child or, in the event of a pregnancy, to terminate it." "111 The court refused to recognize such an action, holding:

[W] believe that such considerations of public policy are better suited to legislative than judicial determination. Persuaded that the generally prevailing view is better reasoned and more consistent with established principles of tort law, we conclude that life, even life with severe defects, cannot be an injury in the legal sense. ${ }^{112}$

Justice Dickson also authored several decisions involving Indiana's various wrongful death statutes. In Ed Wiersma Trucking Co. v. Pfaff, ${ }^{113}$ the court held, as a matter of first impression, that "a dependent next-of-kin may recover damages for the loss of acts of love, care, and affection in a wrongful death action." 114 In Indiana Patient's Comp. Fund v. Brown, ${ }^{115}$ the court held, "Loss of services, when proved, would constitute a pecuniary loss of the type

105. Id. at 1162 .

106. Id.

107. IND. CONST. art. $1, \S 12$.

108. 575 N.E.2d 630 (Ind. 1991).

109. $I d$. at 632 .

110. Id. at 632 .

111. Id. at 633 .

112. Id. at 635 .

113. 678 N.E.2d 110 (Ind. 1997).

114. $I d$.

115. 949 N.E.2d 822 (Ind. 2011). 
contemplated by the [Adult Wrongful Death Statute]."116

Kimberlin v. DeLong, involved the infamous "Speedway Bomber," Brett Kimberlin. ${ }^{117}$ Kimberlin's bomb injured Carl DeLong, who ultimately committed suicide approximately four years after the blast. ${ }^{118}$ His wife sued Kimberlin for wrongful death and the court held, " $[\mathrm{T}]$ he doctrine of superseding cause is inapplicable to willful torts," maintained for death or injury from a suicide or suicide attempt where a defendant's willful tortious conduct was intended to cause a victim physical harm and where the intentional tort is a substantial factor in bringing about the suicide." 120

In Butler v. Indiana Department of Insurance, ${ }^{121}$ Justice Dickson wrote the majority opinion and described that, although "in common law tort actions Indiana has long recognized that a plaintiff may recover the reasonable value of medical services, regardless of whether the plaintiff is personally liable for them or whether they were rendered gratuitously," $" 122$ the Adult Wrongful Death Act "authorizes recovery only of reasonable medical 'expenses necessitated' by another's wrongful conduct." ${ }^{, 23}$ Therefore, "Where charges for medical services are initially billed but thereafter settled for a lower amount pursuant to agreements with health insurers or government agencies, the difference is not a 'necessitated' expense" and not recoverable by an estate. ${ }^{124}$

Finally, in Spangler v. Bechtel, ${ }^{125}$ Justice Dickson wrote the opinion where the court held, although the Child Wrongful Death Act (CWDA) "provides no remedy for wrongful death damages for the death of an unborn child," ${ }^{126}$ parents "who have suffered a stillbirth of their child are not precluded by the CWDA from seeking emotional distress damages in a negligence action." 127

\section{B. Attorney Fees in Wrongful Death Actions}

Justice Dickson's commitment to a pragmatic and reasonable jurisprudential approach is found in his decisions involving attorney fees in wrongful death actions. ${ }^{128}$ The Adult Wrongful Death Act provides, "In an action to recover

\footnotetext{
116. Id. at 824 .

117. 637 N.E.2d 121 (Ind. 1994).

118. Id. at 123 .

119. Id. at 127 .

120. Id. at 128 .

121. 904 N.E.2d 198 (Ind. 2009).

122. Id. at 201-02 (emphasis in original).

123. Id.

124. Id.

125. 958 N.E.2d 458 (Ind. 2011).

126. Id. at 462 .

127. Id. at 463 .

128. See generally McCabe v. Comm'r, Ind. Dep't of Ins., 949 N.E.2d 816 (Ind. 2011); Hematology-Oncology of Ind., P.C. v. Fruits, 950 N.E.2d 294 (Ind. 2011).
} 
damages for the death of an adult person, the damages ... may include but are not limited to ... [ [r] easonable medical, hospital, funeral, and burial expenses necessitated by the wrongful act or omission that caused the adult person's death." 129

In McCabe v. Commissioner, Indiana Department of Insurance, ${ }^{130}$ Justice Dickson authored the opinion and described that the "may include but are not limited to" language in the statute supports his conclusion "that reasonable attorney fees incurred in the prosecution of an action under the Adult Wrongful Death Statute are within the damages permitted by the statute."131

In a companion case, Hematology-Oncology of Indiana, P.C. v. Fruits, ${ }^{132}$ Justice Dickson clarified that although attorney fees are within the damages permitted by the prosecution of an action under the Adult Wrongful Death Statute, when the action is one for medical malpractice, the attorney fee award is subject to the Medical Malpractice Act's fifteen percent limitation and the attorney fees and expenses are included in the provider's liability cap of $\$ 250,000 .^{133}$

Several years later, in Indiana Patient's Compensation Fund v. Holcomb, ${ }^{134}$ Justice Dickson further clarified that, as applied to the Patient's Compensation Fund's liability, "we decline to construe the [fifteen percent] Fee Cap Provision of the Indiana Medical Malpractice Act, Indiana Code [section] 34-18-18-1, to reduce the Patient's Compensation Fund's liability to a plaintiff AWDS claimant." 135 Instead, "The Fee Cap Provision applies only to cap the fees that the plaintiff's lawyer may charge his or her client as to the award the client receives from the Fund, but it does not lessen the Fund's liability to a claimant." 136

\section{Products Liability, Premises Liability, and Comparative Fault}

\section{A. Products Liability}

Justice Dickson's products liability jurisprudence keeps in focus the proper role of the jury and courts, not only in a constitutional separation-of-powers sense, but also in the sense that courts must be careful to police, but not transgress upon, the role of the fact-finder. ${ }^{137}$

Early in his judicial tenure, Justice Dickson wrote the majority opinion in Koske v. Townsend Engineering Co. ${ }^{138}$ holding, "[T] he Indiana open and obvious

129. IND. CODE § 34-23-1-2(c)(1) (2016).

130. 949 N.E.2d at 816 .

131. Id. at 821 .

132. 950 N.E.2d at 294.

133. Id. at 296-97.

134. 17 N.E.3d 255 (Ind. 2014).

135. Id. at 259 .

136. Id.

137. See infra notes 137-51 and accompanying text.

138. 551 N.E.2d 437 (Ind. 1990) (superseded by statute, Ind. Code § 34-20-1-1, -2-2). 
danger rule does not apply to strict liability claims under the Indiana Product Liability Act." ${ }^{\text {"139 }}$ But he then made clear that "the Product Liability Act did not generally supplant areas of product liability law outside of strict liability in tort." 140 Accordingly, with regard to "the applicability of the open and obvious danger rule upon a manufacturer's liability for claims of willful or wanton misconduct," the court held, "the rule should not be extended to preclude claims of willful or wanton misconduct.", 141

Years later, Justice Dickson wrote the opinion in TRW Vehicle Safety Systems, Inc. v. Moore ${ }^{142}$ in which one issue was whether TRW could be held liable for damages caused by a restraint system. ${ }^{143}$ Defendant TRW was aware of and alerted the manufacturer to an alternative design, but defendant Ford decided to use the ultimately inadequate design anyway. ${ }^{144}$ The court held TRW could not be held liable, reversing the lower court's denial of its motion for judgment on the evidence. ${ }^{145}$ Writing for the court, Justice Dickson stated, "The mere availability of an alternative seatbelt design does not establish negligent design by a defendant that lacks the authority to incorporate it into the assembled vehicle."146

Upon holding that fault had been erroneously attributed to TRW, the court had to determine which remedy to provide on appeal: reallocate the fault or remand for a new trial. ${ }^{147}$ Finding that reallocation of fault would require the court to engage in speculation, the court remanded for a new trial on the issue of fault allocation. ${ }^{148}$

Then in Green v. Ford Motor Co. ${ }^{149}$ the court considered a certified question from a federal district court: "Whether, in a crashworthiness case alleging enhanced injuries under the Indiana Products Liability Act, the finder of fact shall apportion fault to the person suffering physical harm when that alleged fault relates to the cause of the underlying accident." 150

The court held the plaintiff's fault could be considered, but only if it was a proximate cause of the injuries for which damages were sought. ${ }^{151} \mathrm{~W}$ riting for the majority, Justice Dickson explained, "[T] he fact-finder shall apportion fault to the injured person only if the fact-finder concludes that the fault of the injured person is a proximate cause of (not merely 'relates to') the injuries for which damages

139. Id. at 442 .

140. Id. at 443 .

141. Id. at 443-44.

142. 936 N.E.2d 201 (Ind. 2010).

143. Id. at 208.

144. Id. at $209,215$.

145. Id. at 216.

146. Id.

147. $I d$. at 227.

148. Id.

149. 942 N.E.2d 791 (Ind. 2011).

150. Id. at 792 .

151. Id. at 796 . 
are sought (not merely the 'underlying accident')."152

\section{B. Premises Liability}

One of Justice Dickson's first premises liability cases was Douglass $v$. Irvin,${ }^{153}$ in which he explained that "the comparative knowledge of landowner and invitee is not a factor in assessing whether the duty exists, [but] it is properly taken into consideration in determining whether such a duty was breached." 154 Accordingly, he overruled the line of cases holding an invitee's "equal or superior knowledge" operates as an exception to the duty owed by a landowner to an invitee. ${ }^{15}$

A few years later, in Bagley v. Insight Communications Co. ${ }^{156}$ Justice Dickson ruled that an employee's "status when injured as an employee of an independent contractor does not deprive him of the right to seek application of one or more of the five exceptions to the rule of non-liability for the torts of an independent contractor." $" 157$

In Paragon Family Restaurant v. Bartolini, ${ }^{158}$ Justice Dickson acknowledged that a jury could properly find that a business owner's fault for failing to prevent an assailant's attack on a patron could surpass the attacker's fault. ${ }^{159}$ Paragon involved a plaintiff who was attacked in a pub parking lot by two minors who had been drinking in the pub. ${ }^{160}$ The defendant pub owner contended that the jury's allocation of fault-eighty percent to the pub and ten percent to each attacker-was against the weight of the evidence, "shock[ed] the conscience," and should not stand. ${ }^{161}$

Writing for the majority, Justice Dickson recognized in this case that a factfinder can allocate a greater portion of fault to the business owner than to the assailants because the opportunity for attack would not have existed but for the business owner's failure to take appropriate action to prevent the attack. ${ }^{162}$ The court held the trial court did not err in letting the jury's allocation of fault stand. ${ }^{163}$ Justice Dickson wrote, "[T]he weight given to the causative role of the Pub may have exceeded that given the relative degree of intentionality of the perpetrators." 164

152. Id. (emphasis in original).

153. 549 N.E.2d 368 (Ind. 1990).

154. Id. at 370 .

155. Id. at 371 .

156. 658 N.E.2d 584 (Ind. 1995).

157. Id. at 588 .

158. 799 N.E.2d 1048 (Ind. 2003).

159. Id. at 1056 .

160. Id. at 1051 .

161. Id. at 1055-56.

162. Id. at 1056 .

163. Id.

164. Id. Years later, Justice Dickson concurred in Santelli v. Rahmatullah, 993 N.E.2d 167 


\section{COMPARATIVE FAUlt AND DUty}

Justice Dickson wrote many decisions establishing Indiana law on comparative fault and duty. Two common themes in his opinions are allowing the jury to decide these issues and applying pragmatism and reasonableness to the judicial approach. ${ }^{165}$

His first decisions involved non-party defendants. He provided the blueprint for how to allocate fault to a dismissed defendant in Bowles v. Tatom ${ }^{166}$ :

In cases where motions at the conclusion of the plaintiff's evidence threaten to remove a party that a remaining defendant claims should remain a party or nonparty for purposes of allocation of fault, such remaining defendant may and should oppose the motion or request that any ruling be delayed until the remaining defendant has an opportunity to present his evidence. In such event, the nature and purpose of the Indiana Comparative Fault Act, together with the efficient administration of justice, would normally result in a trial court's refusal to prematurely dismiss and discharge such parties. ${ }^{167}$

Justice Dickson wrote the following in the majority opinion for a companion case, Cornell Harbison Excavating, Inc. v. May ${ }^{168}$ :

[The Comparative Fault Act] as presently written, coupled with [its] legislative history, clearly evidence[s] the legislature's intent to place the burden of pleading and proving the specific name of the nonparty on the defendant. Thus, by clear implication, the legislature intended a claimant's recovery is not to be diminished by the percentage of fault of unidentified nonparties.

(Ind. 2013), written by Justice Rucker, which held fault of negligent and intentional actors must be compared and allocated to hotel owner and nonparty killer. Id. at 179. Citing Green v. Ford Motor Co., 942 N.E.2d 791 (Ind. 2011), and Paragon, the court recognized that the causative role of a landowner can exceed the relative degree of intentionality of an intentional tortfeasor. Santelli, 993 N.E. $2 d$ at 179 . Accordingly, the court held the trial court did not err in granting plaintiff a new trial on the issue of fault allocation because the court weighed the evidence and judged credibility of witnesses under Indiana Rule of Trial Procedure 59(J) and determined the jury's allocation of fault was against the weight of the evidence. $I d$. at 178-79.

165. See generally Tincher v. Davidson, 762 N.E.2d 1221 (Ind. 2002) (allowing jury's verdict and damage amount to stand despite a damages calculation error); see Pfenning v. Lineman, 947 N.E.2d 392 (Ind. 2011) (finding sports participant acting within the range of ordinary behavior of participants in the sport is reasonable as a matter of law); Dep't of Pub. Welfare, State v. Couch, 605 N.E.2d 165, 168 (Ind. 1992) (noting "it is appropriate" for courts to consider whether settlements are reasonable in declaratory judgment cases).

166. 546 N.E.2d 1188 (Ind. 1989).

167. Id. at 1190 .

168. 546 N.E.2d 1186 (Ind. 1989). 
... [T] he plain meaning and clear language of [the Act] unmistakably require the disclosure of "the name of the nonparty," not merely a generic identification. ${ }^{169}$

Justice Dickson also authored several decisions explaining the contours of the Comparative Fault Act. In Indianapolis Power \& Light Co. v. Brad Snodgrass, Inc.,${ }^{170}$ he "conclude[d] that the law of indemnification is unchanged by the enactment of the Comparative Fault Act[,] ... [h]owever, the fault apportionment process under the Act does not give rise to vicarious liability and resulting indemnification rights." ${ }^{171}$ Further, in Department of Public Welfare, State v. Couch, ${ }^{172}$ Justice Dickson explained that "the proportionate reduction specified in [the Comparative Fault Act's lien reduction provision] applies to all recoveries, whether before or after trial, whether by judgment or settlement." 173

In Tincher v. Davidson, ${ }^{174}$ Justice Dickson offered the court's opinion as to how a trial court could handle jury verdicts under the Comparative Fault Act: "To the extent that there was any residual inconsistency between the second general verdict and its accompanying calculation form, we hold that trial court may have, but was not required, to make further attempts pursuant to [the Comparative Fault Act], or otherwise, to assist the jury in achieving complete consistency." 175

In Kocher v. Getz, ${ }^{176}$ Justice Dickson's opinion explained, "In cases arising under the [Comparative Fault] Act, a defense of mitigation of damages based on a plaintiff's acts or omissions occurring after an accident or initial injury is not properly included in the determination and allocation of 'fault' under the Act."177 Instead, "The phrase "unreasonable failure to avoid an injury or to mitigate damages' included in the definition of 'fault' under [the Act] applies only to a plaintiff's conduct before an accident or initial injury." 178

An excellent example of Justice Dickson's pragmatic approach to comparative fault and duty issues is found in Pfenning v. Lineman ${ }^{179}$ In Pfenning,

169. Id. at 1187.

170. 578 N.E.2d 669 (Ind. 1991).

171. Id. at 673 .

172. 605 N.E.2d 165 (Ind. 1992).

173. Id. at 168 (interpreting IND. CODE 34-4-33-12).

174. 762 N.E.2d 1221 (Ind. 2002).

175. Id. at 1226. In Tincher, the court concluded,

The general verdict expressed the jurors' unanimous intent to award a judgment of $\$ 150,000.00$ to the plaintiff.

The verdict itself was not internally inconsistent, illogical, or impossible . . . $[\mathrm{T}]$ he general verdict should not have been impeached by the calculation form. We conclude that the trial court erred in declaring a mistrial.

Id.

176. 824 N.E.2d 671 (Ind. 2005).

177. Id. at 674 (emphasis omitted).

178. Id. (emphasis omitted).

179. 947 N.E.2d 392 (Ind. 2011). 
a grandfather took his granddaughter to a golf outing, where she assisted him in operating the beverage cart. ${ }^{180}$ While operating the beverage cart, the granddaughter was injured after she was struck in her mouth by a golf ball. ${ }^{181}$ The granddaughter filed a negligence action against the golfer who hit the ball that struck her, the tavern that promoted the event, the fraternal lodge that owned and operated the golf course, and her grandfather. ${ }^{182}$

Addressing issues of duty under the Comparative Fault Act, Justice Dickson noted that "a plaintiff"s recovery will be diminished or precluded depending upon the degree of the plaintiff's own fault." ${ }^{183}$ When dealing with negligence claims arising from sport participation, "rather than focusing upon the inherent risks of a sport as a basis for finding no duty, which violates Indiana statutory and decisional law, the same policy objectives can be achieved without inconsistency with statutory and case law by looking to the element of breach of duty." 184

However, the court noted, "Breach of duty usually involves an evaluation of reasonableness and thus is usually a question to be determined by the finder of fact in negligence cases." " apply in sports cases: "But in cases involving sports injuries, and in such cases only, we conclude that a limited new rule should apply acknowledging that reasonableness may be found by the court as a matter of law." 186 Therefore, "We hold that, in negligence claims against a participant in a sports activity, if the conduct of such participant is within the range of ordinary behavior of participants in the sport, the conduct is reasonable as a matter of law and does not constitute a breach of duty." "187

Justice Dickson's final opinion dealing with issues of duty was Yost v. Wabash College, ${ }^{188}$ where the court held neither the college nor the national fraternity owed or assumed a duty to a fraternity pledge for injuries resulting from fraternity hazing. ${ }^{189}$ In Yost, the college leased a fraternity house to the local fraternity. ${ }^{190}$ Although both the college and the national fraternity "engaged in educational outreach programs to encourage and enhance appropriate student behavior and to discourage hazing," no duty existed to the pledge because that "specific "undertaking' did not extend to direct oversight and control of the behavior of individual student members of the local fraternity." 191

This is contrasted with the local fraternity where the court found that the

180. Id. at 397.

181. Id.

182. Id. at 396.

183. Id. at 399.

184. Id. at 403 .

185. Id.

186. Id.

187. Id. at 404 .

188. 3 N.E.3d 509 (Ind. 2014).

189. Id. at 524 .

190. Id. at 516 .

191. Id. at 518. 
pledge may be able to establish at trial "that the local fraternity undertook to render supervisory services intended to reduce the risk of harm to members like Yost, that upon which supervision Yost relied, and further that by failing to exercise reasonable care the local fraternity increased the risk of harm to Yost." ${ }^{192}$

\section{DEFAMATION}

Justice Dickson issued two majority opinions involving defamation claims. In Bals v. Verduzco, ${ }^{193}$ the court held "employee evaluation information communicated intracompany to management personnel may be considered published for purposes of a defamation action." 194 However, "To accommodate the important role of free and open intracompany communications and legitimate human resource management needs, the qualified privilege is available to protect personnel evaluation information communicated in good faith." 195

Years later, Justice Dickson wrote the opinion in Williams v. Tharp, a defamation case involving communications made to law enforcement while reporting criminal activity. ${ }^{196}$ Justice Dickson recognized the competing interests involved when he wrote there is "the desirable public interest served by citizens" awareness and prompt reporting of suspected criminal activity, even when uncertain." 197 However, the court recognized one must also consider that "a reporting citizen may, out of an excess of caution or even for a nefarious purpose, make false accusations, and our citizens' equally valid interest in having reputations untarnished by false imputations of criminal misconduct has been a cornerstone of defamation law for hundreds of years." 198

Accordingly, " $[\mathrm{C}]$ ommunications made to law enforcement to report criminal activity are qualifiedly privileged." 199 Justice Dickson described, that in order to defeat the qualified privilege, the plaintiff must prove the speaker made the statement knowing the statement was false, or that the statement was so obviously mistaken as to support a reasonable inference that an employee had lied-rejecting the "reckless disregard" standard in this circumstance. ${ }^{200}$

\section{EMPloyment LAW CASES: RespondeAt SuPERIOR \& RETALIATORY DischaRgE}

Justice Dickson twice opined as to the doctrine of respondeat superior, which holds "[a]n employer ... vicariously liable for the wrongful acts of employees

192. Id. at 523 .

193. 600 N.E.2d 1353 (Ind. 1992).

194. Id. at 1356.

195. Id.

196. 914 N.E.2d 756, 761 (Ind. 2009).

197. Id. at 763 .

198. Id.

199. Id.

200. Id. at 765 . 
committed within the scope of employment."201

In Warner Trucking, Inc. v. Carolina Casualty Insurance Co. ${ }^{202}$ Justice Dickson wrote the following on behalf of the majority of the court, "The critical inquiry is not whether an employee violates his employer's rules, but whether the employee is in the service of the employer." ${ }^{203}$ Thus, "Even though an employee violates the employer's rules, orders, or instructions, or engages in expressly forbidden actions, an employer may be held accountable for the wrongful act if the employee was acting within the scope of employment." 204

In Barnett v. Clark, ${ }^{205}$ Justice Dickson quoted the latest Restatement, "An employee acts within the scope of employment when performing work assigned by the employer or engaging in a course of conduct subject to the employer's control." ${ }^{206}$ Conversely, "An employee's act is not within the scope of employment when it occurs within an independent course of conduct not intended by the employee to serve any purpose of the employer."207

Justice Dickson addressed a different employment-related issue in Meyers $v$. Meyers,${ }^{208}$ holding, "Indiana generally follows the employment at will doctrine, which permits both the employer and the employee to terminate the employment at any time for a 'good reason, bad reason, or no reason at all." ${ }^{209}$ Therefore, "[T]he employment at will doctrine precludes [a discharged employee] from asserting an action for wrongful discharge in retaliation for asserting a claim for unpaid wages ...."210

\section{Statutory Causes of Action and Limitations on ACtions}

\section{A. Medical Malpractice}

Justice Dickson has written several opinions dealing with substantive issues under the Medical Malpractice Act. The first was Chaffee v. Seslar, in which the plaintiff alleged negligence in connection with a sterilization procedure. ${ }^{211}$ Justice Dickson, writing for the majority stated: "Recoverable damages may include pregnancy and childbearing expenses, but not the ordinary costs of raising and

201. Warner Trucking, Inc. v. Carolina Cas. Ins. Co., 686 N.E.2d 102, 105 (Ind. 1997).

202. Id. at 102 .

203. Id. at 105 .

204. Id.

205. 889 N.E.2d 281 (Ind. 2008).

206. Id. at 284 (quoting Restatement (ThiRd) of AGENCY § 7.07(1) (AM. LAW Inst. 2006)); see also Restatement (ThiRd) OF AgEnCy $§ 2.04$ (AM. LAW. Inst. 2006).

207. Barnett, 889 N.E.2d at 284 (quoting Restatement (ThiRd) of Agency $\S 7.07$ (2) (Am. LAW. ISNT. 2006)) (emphasis omitted).

208. 861 N.E.2d 704 (Ind. 2007).

209. Id. at 706 .

210. Id.

211. 786 N.E.2d 705, 706 (Ind. 2003). 
educating a normal, healthy child." ${ }^{212}$

Then in Spangler v. Bechtel, ${ }^{213}$ the court addressed whether a plaintiff's claims for emotional distress were controlled by a single or multiple caps under the Medical Malpractice Act. ${ }^{214}$ When discussing caps and derivative claims, Justice Dickson mentioned that "claims of emotional distress represent injuries directly inflicted on a plaintiff and are not derivative in the traditional sense."215 He went on to write, "Claims for negligent infliction of emotional distress, if arising from alleged medical malpractice, are subject to the [Malpractice Act caps] not because they are derivative but because they are 'otherwise' a result of alleged malpractice." 216

\section{B. Dram Shop Liability}

At the time of Picadilly, Inc. v. Colvin,${ }^{217}$ Indiana's Dram Shop Act provided, "It is unlawful for a person to sell, barter, deliver, or give away an alcoholic beverage to another person who is in a state of intoxication if the person knows that the other person is intoxicated." 218 The plaintiff in Picadilly brought a negligence action against the defendant bar, which had served an intoxicated driver. ${ }^{219}$ The defendant argued that there was no longer a common law cause of action for dram shop liability and that it did not violate the statute, so there could also be no statutory basis for liability. ${ }^{220}$

Rejecting this argument, Justice Dickson described:

[C]ommon law liability [exists] notwithstanding the existence of such statute.

Under the common law of this State, persons engaged in the business of furnishing alcoholic beverages are not granted special exemption or privilege. [Rather,] [t]hey are under the same duty to exercise ordinary and reasonable care in the conduct of their operations as are those involved in businesses which are not alcohol related. Such ordinary and reasonable care must be exercised for the safety of others whose injuries should reasonably have been foreseen or anticipated. ${ }^{221}$

212. Id. at 708 .

213. 958 N.E.2d 458 (Ind. 2011).

214. Id. at 471 .

215. $I d$.

216. Id. at 472 .

217. 519 N.E.2d 1217 (Ind. 1988).

218. IND. CoDE $\S 7.1-5-10-15$ (1987) (amended 2014).

219. 519 N.E.2d at 1219.

220. Id. at 1220 .

221. Id. 


\section{Statutory Immunity Under the Indiana Tort Claims Act}

In two companion cases, Patrick v. Miresso ${ }^{222}$ and City of Indianapolis $v$. Garman, ${ }^{223}$ Justice Dickson addressed an issue of first impression under the Indiana Tort Claims Act and wrote, "[A] governmental unit and its police officer are not immune from liability for injuries caused by the officer's negligent operation of a police vehicle while pursuing a fleeing suspect.,"224

\section{Other Miscellaneous Tort Opinions}

\section{A. First-Party Spoliation}

In Gribben v. Wal-Mart Stores, Inc. ${ }^{225}$ Justice Dickson determined

the common law of Indiana to be that, if an alleged tortfeasor negligently or intentionally destroys or discards evidence that is relevant to a tort action, the plaintiff in the tort action does not have an additional independent cognizable claim against the tortfeasor for spoliation of evidence under Indiana law. ${ }^{226}$

\section{B. Alternate Dispute Resolution}

In a matter of first impression, Justice Dickson in Vernon v. Acton, ${ }^{227}$ wrote the majority opinion stating, "[T] he mediation confidentiality provisions of our A.D.R. Rules extend to and include oral settlement agreements undertaken or reached in mediation." 228 Additionally, "[u]ntil reduced to writing and signed by the parties, mediation settlement agreements must be considered as compromise settlement negotiations under the applicable A.D.R. Rules and Evidence Rule 408 " and, therefore, no evidence of the oral agreement is admissible. ${ }^{229}$

\section{Insurance Duty to Defend}

In Dreaded, Inc. v. St. Paul Guardian Insurance Co., ${ }^{230}$ Justice Dickson wrote the majority opinion holding, "[A]n insurer cannot defend a claim of which it has no knowledge. The function of a notice requirement is to supply basic information to permit an insurer to defend a claim."231 Thus, "The insurer's duty to defend simply does not arise until it receives the foundational information

222. 848 N.E.2d 1083 (Ind. 2006).

223. 848 N.E.2d 1087 (Ind. 2006).

224. Patrick, 848 N.E.2d at 1084; see generally Garman, 848 N.E.2d at 1088.

225. 824 N.E.2d 349 (Ind. 2005).

226. Id. at 355 .

227. 732 N.E.2d 805 (Ind. 2000).

228. Id. at 810 .

229. Id.

230. 904 N.E.2d 1267 (Ind. 2009).

231. Id. at 1273 . 
designated in the notice requirement. Until an insurer receives such enabling information, it cannot be held accountable for breaching this duty." ${ }^{232}$

\section{Repressed Memories}

In Fager v. Hundt, ${ }^{233}$ the plaintiff filed a tort action against her father, alleging sexual abuse during her minority. ${ }^{234}$ The father sought to dismiss the action on statute of limitations grounds, claiming that she had failed to file the action within two years after she reached the age of majority. ${ }^{235}$ The plaintiff argued that she "had suppressed all memory or recollection of the incestuous conduct" until six months before she filed her complaint and, therefore, the discovery rule should apply. ${ }^{236}$

Justice Dickson, however, "decline[d], in cases of childhood injuries, to apply the discovery rule subjectively based upon the child's actual knowledge." ${ }^{237} \mathrm{He}$ wrote that "[b]ecause of the natural and legal obligations of parents to protect and care for their children, [the court] hold[s] that 'discovery' of a cause of action by a child's parent, even absent actual cognition or memory by the child, shall be imputed to the child," and this imputation "shall conclusively constitute the accrual of an action within the meaning of the disability statute, Indiana Code section 34-1-2-5, thus allowing the minor two years after reaching majority within which to commence suit.",238

This seemingly harsh result, however, was lessened by the court in providing that "this general rule must be subject to an exception when, as in the present case, the plaintiff's claim asserts childhood injury from the intentional felonious act of a parent. ${ }^{" 239}$ An exception must exist because "[u]nder such circumstances we cannot presume that the parent informed the child of significant childhood events." ${ }^{240}$ In these circumstances, "the doctrine of fraudulent concealment should be available to estop a defendant from asserting the statute of limitations 'when he has, either by deception or by a violation of duty, concealed from the plaintiff material facts thereby preventing the plaintiff from discovering a potential cause of action." "241

232. $I d$

233. 610 N.E.2d 246 (Ind. 1993).

234. Id. at 248 .

235. Id.

236. Id.

237. Id. at 251 .

238. Id.

239. Id

240. Id.

241. Id. (quoting Burks v. Rushmore, 534 N.E.2d 1101, 1104 (Ind. 1989)). 